\title{
PATHOGENESIS OF FIBROMYALGIA IN PATIENTS WITH AUTOIMMUNE DISEASES: SCOPING REVIEW FOR HYPOTHESIS GENERATION
}

\author{
Received: Aug 24, 2019
}

Accepted: Sept 27,2019

Sakir Ahmed ${ }^{\mathbf{1}}$ http://orcid.org/0000-0003-4631-311X

Able Lawrence ${ }^{2}$ https://orcid.org/0000-0003-3439-8048

1Department of Clinical Immunology \& Rheumatology, Kalinga Institute of Medical Sciences (KIMS), KIIT University, Bhubaneswar, India 2Department of Clinical Immunology\& Rheumatology, Sanjay Gandhi

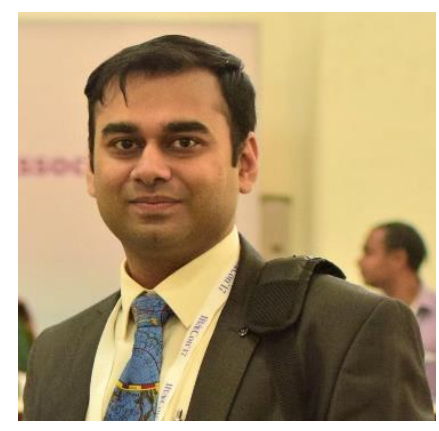

Postgraduate Institute of Medical Sciences, Lucknow, India

\section{*Corresponding author:}

Sakir Ahmed, MD Assistant Professor, Department of Clinical Immunology \& Rheumatology, Kalinga Institute of Medical Sciences (KIMS), KIIT University

Bhubaneswar-751024, India;

Twitter handle: @drSaki5; E-mail: sakir.ahmed@kims.ac.in

\begin{abstract}
Introduction: Fibromyalgia (FM) prevalence is much higher in patients with other rheumatic diseases than in the general population. This leads to increase in the perceived disease activity scores and prevents patients from reaching remission. Elucidating the pathogenesis of such "secondary" FM can help alleviate some unmet needs in these diseases.

Methods: MEDLINE and Scopus databases were searched for a scoping review for hypothesis generation regarding the genesis of secondary FM.

Results: FM has been postulated to be due to cytokine dysfunction, neurogenic neuroinflammation, stress, including social defeat, sleep disturbances, sympathetic overactivity, and small fibre neuropathy. These factors increase in most autoimmune and autoinflammatory diseases. Further the evidence for the role of these factors in the pathogenesis of FM is seems strong. Metabolic syndrome and mitochondrial dysfunction are also associated with FM, but it is difficult to distinguish between cause and effect.

Conclusion: FM is the common phenotype arising from the amalgamation of various aetiologies. Recruitment or amplification of the above 6 factors by various rheumatic diseases may thus lead precipitation of secondary FM in susceptible individuals.
\end{abstract}




\section{Central Asian Journal of Medical Hypotheses and Ethics| \\ 2020; Vol 1}

Keywords: Fibromyalgia, Pathogenesis, Neuroinflammation, Autoimmunity, Pain

How to cite: Ahmed S., Able L. Pathogenesis of fibromyalgia in patients with autoimmune diseases: scoping review for hypothesis generation. Cent Asian J Med Hypotheses Ethics 2020;1(1): 43-54. https://doi.org/10.47316/caimhe.2020.1.1.06

$\begin{array}{ll}\text { Abbreviations } & \\ \text { FM: } & \text { Fibromyalgia } \\ \text { IL: } & \text { Interleukin } \\ \text { Gp130: } & \text { Glycoprotein-130 } \\ \text { CCL: } & \text { C-C Motif Chemokine Ligand } \\ \text { MEFV: } & \text { MEditerranean FeVer gene } \\ \text { (encodes pyrin protein) } & \\ \text { CSF: } & \text { Cerebrospinal fluid } \\ \text { TNF-a: } & \text { Tumour necrosis factor-a } \\ \text { IFN: } & \text { Interferon } \\ \text { OSA: } & \text { Obstructive sleep apnoea } \\ \text { a7nAChR: } & \text { Alpha7 Subunit Of Nicotinic } \\ \text { Acetylcholine } & \text { Receptor } \\ \text { COMT } & \text { Cateholamine-O- Methyl } \\ \text { Transferase } & \\ \text { TRPV } & \text { Transient Receptor Potential } \\ \text { Vanilloid } & \\ \text { SCN9A Sodium } & \text { Voltage-Gated Channel Alpha } \\ \text { Subunit 9 } & \\ \text { CRPS } & \text { Complex Regional Pain Syndrome }\end{array}$

\section{INTRODUCTION}

Fibromyalgia (FM) is a syndrome of widespread pain with other overlapping somatic symptoms. It is a frequent comorbidity in several rheumatic diseases. The prevalence of $\mathrm{FM}$ in the general population ranges from 1.5 to $2 \%$ (3-6\% in women) [1]. However, it is much higher in rheumatoid arthritis (9-30\%) [2], axial spondyloarthritis (4-25\%) [3], lupus (6.2\%) [4], and Sjögren syndrome(15\%) [5]. Prevalence of FM was higher even in nonrheumatic diseases like primary immunodeficiency (19\%) [6] and thyroid disease [7]. Though the prevalence figures based on different classification criteria may differ [8], the proportions of "primary" to "secondary" FM remain the same. The presence of concomitant FM leads to increased pain, fatigue and physical limitations [9] besides inflating disease activity scores and preventing attainment of remission [10].

With the advent of various targeted therapies in various inflammatory rheumatological conditions, remission or low disease activity is a viable target.
However, there are concerns about unmet needs in these diseases [11]. Despite the resolution of inflammation, patients still perceive pain and have poor quality of life. A large proportion of this may be due to the presence of concomitant FM [12]. Therefore, dealing effectively with fibromyalgia can potentially improve the outcomes.

The high prevalence of secondary FM, that is FM comorbid with other rheumatic diseases, seem to suggest that chronic inflammation might be a factor that precipitate or unmask FM in susceptible individuals. In this article we attempt to understand various theories underpinning the pathogenesis of FM, and then attempt to apply these concepts to explain how various rheumatic diseases can lead to the genesis of secondary FM. We also go beyond conventional ideas to propose an alternative hypothesis that FM itself may predispose to other rheumatic diseases.

\section{SEARCH STRATEGY}

Scopus and MEDLINE databases were queried with search strings "Fibromyalgia", "aetiology OR pathogenesis OR aetiopathogenesis" and "rheumatic diseases" as per standard practices for biomedical reviews [13]. Original articles were predominantly analyzed along with highly relevant hypotheses and reviews. The two authors independently searched through the articles and made the lists of causes that they felt can contribute to the pathogenesis of secondary FM. The two lists were then amalgamated.

\section{BASIC HYPOTHESIS}

FM is the common phenotypic expression of a number of different mechanisms leading to chronic persistent and widespread pain. However, these mechanisms can have overlapping aetiologies further complicating the picture. We attempt to demonstrate how different mechanisms can contribute to a FM phenotype in autoimmune and other inflammatory diseases. 


\section{Central Asian Journal of Medical Hypotheses and Ethics| \\ 2020; Vol 1}

\section{A. Cytokine dysregulation model of FM}

Dysregulated cytokines processing has long been viewed a basis for FM [14]. Early candidates were interleukin-2 and soluble glycoprotein-130 [15,16]. Some studies showed no difference in serum cytokines: there is plenty of controversy on the topic [17]. It has been suggested that a subset of patients have the so-called inflammatory FM with increased levels of acute-phase reactants [18]. Other cytokine abnormalities have been described in cerebrospinal fluid (CSF). Randomized controlled trials have supported this hypothesis by demonstrating changes in cytokine profiles in FM patients $[19,20]$. Also exome sequencing of patients with FM has shown multiple polymorphisms in immune related genes (CCL11, CCL4 and MEFV) [21]. If this hypothesis is true, it is possible to explain secondary FM in patients with autoimmune and autoinflammatory diseases: the primary disease changes the cytokine profile that leads to manifestations of FM in genetically susceptible individuals.

Parallels can be drawn from the pathogenesis of depression: mice injected with lipopolysaccharide show clinical signs of depression [22]. Similarly, patients with depression and post-traumatic stress disorder can have elevated levels of interleukin- 6 and blunted responses of IL-6 to steroids [23].

Patients with primary fibromyalgia have decreased cytokines production in vitro for reasons that are unclear. This hyporesponsiveness is generalised affecting multiple cytokines and not any one in particular, which is exploited by the patented test for FM [24]. Chronic activation and stress might potentially depress stimulated cytokine production. However, this could be a secondary phenomenon. Experimental studies in non-human primates found immune status to correlate with social hierarchy [25].

\section{B. Neurogenic neuroinflammation}

While cytokine abnormalities are usually minor in the serum, some definitive changes have been noted in the CSF $[26,27]$. In cases of peripheral neuropathic pain, the CSF cytokine profile shows increase in IL-8 and the chemokine fractalkine, changes similar to those observed in FM [28]. Peripheral blood mononuclear cells have been used to induce microglia-like cells. Such induced microglia-like cells obtained from FM patients have been shown to express higher levels of tumour necrosis factor (TNF)- $a$ at mRNA and protein levels as compared to cells obtained from healthy controls. These have led to the concept of neuroinflammation in FM [29]. Neuron-induced inflammation leads to damage of surrounding neurons, perpetuating a vicious cycle of neurogenic neuroinflammation. Evidence for the role of neurogenic neuroinflammation has been reported in depression [30]. Chronic widespread pain is associated with accelerated biological [31] aging and also with increased mortality [12]. Thus accelerated neuronal aging may also contribute further neuroinflammation. Indirect evidence for this can be the higher rates of dementia seen in patients with FM (adjusted hazard ratio of 2.77) [32].

Chronic autoimmune diseases are expected to exhibit similar neuroinflammation that might predispose to FM. For example, in neuropsychiatric lupus, interferon (IFN) has been shown to cause microglial activation leading to synapse pruning. The rodent models used in this elegant paper exhibit various behaviour phenotypes overlapping with features of fibromyalgia [33]. The gut microbiome in FM has been shown to alter glutamate metabolism. Glutamate is a excitatory neurotransmitter that has been implicated in neuropsychiatric lupus [34]. A "brain-fog" similar to "fibrofog" has thus been postulated in lupus [35]. Thus there seems to be good evidence of neuroinflammation in lupus leading to certain FM characteristics.

Another caveat supporting the neuroinflammation theory is the role of macrophages in the resolution of pain. Pain is naturally perceived in the higher neural areas in response to noxious stimulus to nerves (nociceptors) in the periphery. However, the macrophage is a key mediator in the resolution of inflammation as opposed to neurons or microglial cells [36]. This strengthens the relationship between inflammation and pain perception.

\section{Stress as a basis for FM}

Chronic stress can activate neuroinflammation. A systematic review has shown consistent effect of psychosocial stress in activating microglia in the hippocampus. There is also evidence that it can 


\section{Central Asian Journal of Medical Hypotheses and Ethics| \\ 2020; Vol 1}

activate microglia in other regions of the brain [37]. The chronic stress can both increase central sympathetic outflow and alter the immune response of the individual. It has been shown in animal models that chronic stress in the form of social defeat increases the susceptibility to pain and hyperalgesia $[38,39]$.

Social defeat is the conflict between member of the same species (resident versus intruder) that leads to emotional and psychological stress [40]. The loss of a mental confrontation or physical fight induces suppression of aggression and other behaviour reminiscent of symptoms of various human psychiatric illnesses [41]. Thus, social defeat models in rodents provide good simulations to study depression, anxiety and even fibromyalgia in the laboratory. Most chronic diseases can work in the same way inducing microglial activation and thus decrease pain thresholds. Prolonged social stress can cause microglial activation and monocyte infiltration in the brain leading to behavioural changes ranging from anxiety and depression to violent anti-social behaviour [42]. Social defeat can change the social standing of an individual that determines the individual's immune responsiveness and regulation [25].

There are several studies showing a high prevalence of post-traumatic stress disorder and childhood adverse conditions in patients with fibromyalgia. This has been validated in a systematic review that past traumatic events can precipitate chronic widespread pain [43].

\section{Sleep disorders and FM}

Some of the first subjective evidence of existence of FM as a distinct entity was provided by polysomnography studies including increasing alpha to delta ratio in successive sleep cycles [44]. Even epidemiological studies have shown that sleep disturbances predispose to chronic widespread pain. Similarly, even sleep deprivation in healthy individuals can induce symptoms of FM [45]. The relationship between FM and obstructive sleep apnoea (OSA) is known, but often FM patients are not evaluated for OSA [46]. Most rheumatic diseases cause sleep disruption [47]. Inflammatory polyarthritis like spondylarthritis are linked to night pains. Thus rheumatic diseases can lead to poor quality of sleep that will also predispose to FM.

\section{E. Sympathetic nervous system in various rheumatic diseases, including fibromyalgia}

The cross-talk between the immune and the nervous systems has been long recognised [48]. Before the advent of methotrexate, high dose propranolol had been tried for rheumatoid arthritis [49]. The role of the nervous system in determining chronicity of arthritis has been well recognised. Vagal nerve stimulation or activation of the alpha7 subunit of nicotinic acetylcholine receptors ( $a 7 n A C h R$ ) has been shown to alleviate inflammatory arthritis [50,51].

Sympathetic overactivity has been reported in FM in two-thirds of studies in a review [52]. Sympathetic sudomotor response of skin in FM patients has longer latency compared to that in healthy controls [53]. The arteriole-venule shunts in skin have increased peptidergic innervation in FM [54]. Thus, there is ample evidence of involvement of the peripheral sympathetic system in FM. It can be a common pathway for both inflammation and pain. The catechol-0-methyltransferase (COMT) Val158Met polymorphism has been shown to be associated with severity of FM in a meta-analysis [55]. Chronic inflammatory arthritis may lead to sympathetic dysfunction that predisposes the nervous system to sustained widespread pain perception.

Peripheral arthritis or even a photosensitive dermatitis will cause minimal tissue damage, including damage to free nerve endings. Such damage can potentiate neurotransmitter release upstream, leading to central sensitization of the spinal cord and brain. Repetitive activation of unmyelinated type $C$ fibres leads to temporal summation. Similarly, non-nociceptive $A \beta$ fibres activation can add to dynamic mechanical allodynia while nociceptive Aסfibres can add to hyperalgesia [56].

\section{F. Peripheral small fibre neuropathy model of FM}

Both functional and structural studies have demonstrated small fibre neuropathy in patients with FM [57]. Punch biopsies have demonstrated 


\section{Central Asian Journal of Medical Hypotheses and Ethics| \\ 2020; Vol 1}

damage to unmyelinated nerve fibres in up to $50 \%$ of FM patients; and some authors are recommending routine skin biopsy in FM patients [58]. Alternatively, even confocal microscopy of the cornea can pick up decreased nerve fibre thickness [59].

Genetic polymorphism studies have supported this concept. Polymorphisms in transient receptor potential vanilloid (TRPV) channel 2 and 3 genes have been shown to be associated with FM diagnosis and with severity of symptoms respectively in Korean patients [60]. Similarly, the SCN9A gene encoding a sodium channel in dorsal root ganglia has been shown to be associated with severe FM in Mexican patients [61].

Neuropathy is a known feature of rheumatic diseases. Studies have shown biopsy proof of small fibre neuropathy in Sjögren syndrome [62]. All types of peripheral neuropathies have been reported in the context of rheumatic diseases. Thus, a question arises whether autoimmune disease can unmask neuropathy leading to FM.

Complex regional pain syndrome (CRPS) has characteristics and mechanisms similar to sympathetic activation in FM, but is limited to one limb. FM may be considered a forme fruste of CRPS. Quantitative electroencephalography studies have demonstrated similarities between the two [63], and neuroinflammation has also been implicated in both [29].

\section{G. Linkage with metabolic syndrome: confounder or causal relationship?}

FM is linked to metabolic syndrome [64]. Most rheumatic diseases have been shown to increase cardiovascular risk. This can be viewed in two ways. First, presence of FM and other rheumatic diseases induce lifestyle changes, leading to reduced physical activity and increased body mass index. The second alternate view is that there may be common genes or environmental factors that predispose to both metabolic syndrome and FM. This second line of thought seems to imply that there might be common pathways in pathogenesis of both. There are studies of metabolomics demonstrating altered levels of various metabolites in FM [65].
Patients with FM have mitochondrial dysfunction that can be reversed by caloric restriction or by metformin [66]. Mitochondrial dysfunction, oxidative stress and neuroinflammation go hand in hand in the FM, and this inflammation correlates with perceived pain [67]. The relationship between innate immune activation and mitochondrial dysfunction has been demonstrated for major depressive disorder [68]. There might be similar mechanisms active in FM; with the underlying metabolic syndrome causing mitochondrial dysfunction and altered cellular energetics predisposing to chronic fatigue and widespread pain.

\section{H. Opioid induced lowered pain thresholds}

Opioid-induced hyperalgesia has been compared to the central sensitization in FM [69]. Morphine induced hyperalgesia in mice has been shown to be dependent on the spinal microglia [70]. This would suggest that opioids can lead to microglial activation.

In chronic rheumatological diseases there might be chronic endogenous opioid secretion leading to receptor fatigue. It has been shown that one abnormality in primary FM is the low prevalence of opioid mu-receptor and reduced sensitivity of this receptor to endorphins. The altered endogenous opioid/receptor functioning can lead to widespread pain and other manifestations of FM.

\section{Reverse causality: Fibromyalgia increasing risk of autoimmune diseases}

Scientific rigor also entails that we explore the possibility of reverse causality. The strong association of $\mathrm{FM}$ with autoimmune rheumatic diseases can be explained even if FM predisposes to increased risk of rheumatic disease. A person with FM who develops rheumatoid arthritis is likely to be detected earlier. Such a person would already be in contact with healthcare, and more often than not, have certain investigations (like rheumatoid factor or anti-citrullinated peptide antibody positivity) that can make diagnosis of early RA easier. It is difficult to state whether FM increases the risk of rheumatoid arthritis or FM simply unmasks RA earlier. 
There are hypotheses related to FM predisposing to chronic inflammatory arthritis. The stimulation due to small fibre neuropathy or sympathetic activation in FM might be the same signal that triggers inflammatory arthritis. The neurogenic neuroinflammation may provide a basis for viral arthritis, and arthritis may not resolve with the resolution of viremia, proceeding to chronic disease indistinguishable from rheumatoid arthritis. Such hypotheses will be difficult to prove, but should be considered in exploring the relationship between FM and rheumatic diseases.

\section{POTENTIAL IMPLICATIONS OF THE UNIFYING HYPOTHESIS}

The hypothesis presented (Fig. 1) is that FM is the phenotypic expression of a number of different pathological processes that may or may not overlap in the susceptible individual. Since many of these changes also take place during chronic inflammatory illnesses, such illness will increase the chances of developing secondary FM.

In Central Asia, South Asia and Asia Pacific countries, the prevalence of FM has been reported to range from 0.6 to $4 \%$, which is comparatively less than in the United States and Canada [71,72]. But the prevalence of inflammatory rheumatic diseases is high in these regions. And in many of these countries, the disease burden is high with a large proportion of patients having moderate to high disease activity. Thus, it is imperative for these countries to consider secondary FM as an important clinical condition increasing disease activity scores and a potential factor of poor quality of life in these patients. To test the reverse causality hypothesis, there should be a powered cohort of primary FM matched with a control. Both should be followed up for adequate time to collect the incidence of rheumatic disease in each.

This scoping review focussed on fibromyalgia in inflammatory rheumatic diseases. However, FM is also prevalent in many other chronic conditions such as hypothyroidism, diabetes mellitus, haemodialysis, etc. We have not dwelt on hypotheses linking such non-inflammation diseases with FM. But the basic concept will remain the same, viewed in association with cytokine disbalance, neurogenic neuroinflammation, autonomic neuropathy, and altered sleep.

\section{CONCLUSION}

It is likely that FM is the final manifestation of heterogenous aetiologies that lead to a similar phenotype of widespread pain and various somatic symptoms. Rheumatic diseases can unmask the susceptibility to FM via cytokine dysregulation, neurogenic neuroinflammation, sleep disturbances, autonomic dysregulation and/or small nerve damage. They will also add to chronic stress and act as peripheral pain generators that might precipitate FM symptoms in such a predisposed individual.

\section{FUNDING}

None

\section{AUTHOR CONTRIBUTIONS}

$S A$ and $A L$ designed the study and SA made the literature searches. SA drafted the initial manuscript and it was critically revised by both. Both authors have approved the final manuscript and take responsibility for the contents of the manuscript.

\section{ACKNOWLEDGEMENTS}

The authors would like to acknowledge Mohini Sinha, MS, for her critical proof-reading of the manuscript.

\section{CONFLICTS OF INTEREST}

SA and AW declare that they have no conflict of interest, including no relationship with pharmaceutical companies.

\section{DISCLAIMER}

No part of the manuscript is copied from elsewhere. It expresses the personal opinions of the authors except in places where due references are provided for the source of data/hypotheses. 


\section{Central Asian Journal of Medical Hypotheses and Ethics| \\ 2020; Vol 1}

Figure 1. Flow-chart of proposed unifying hypothesis

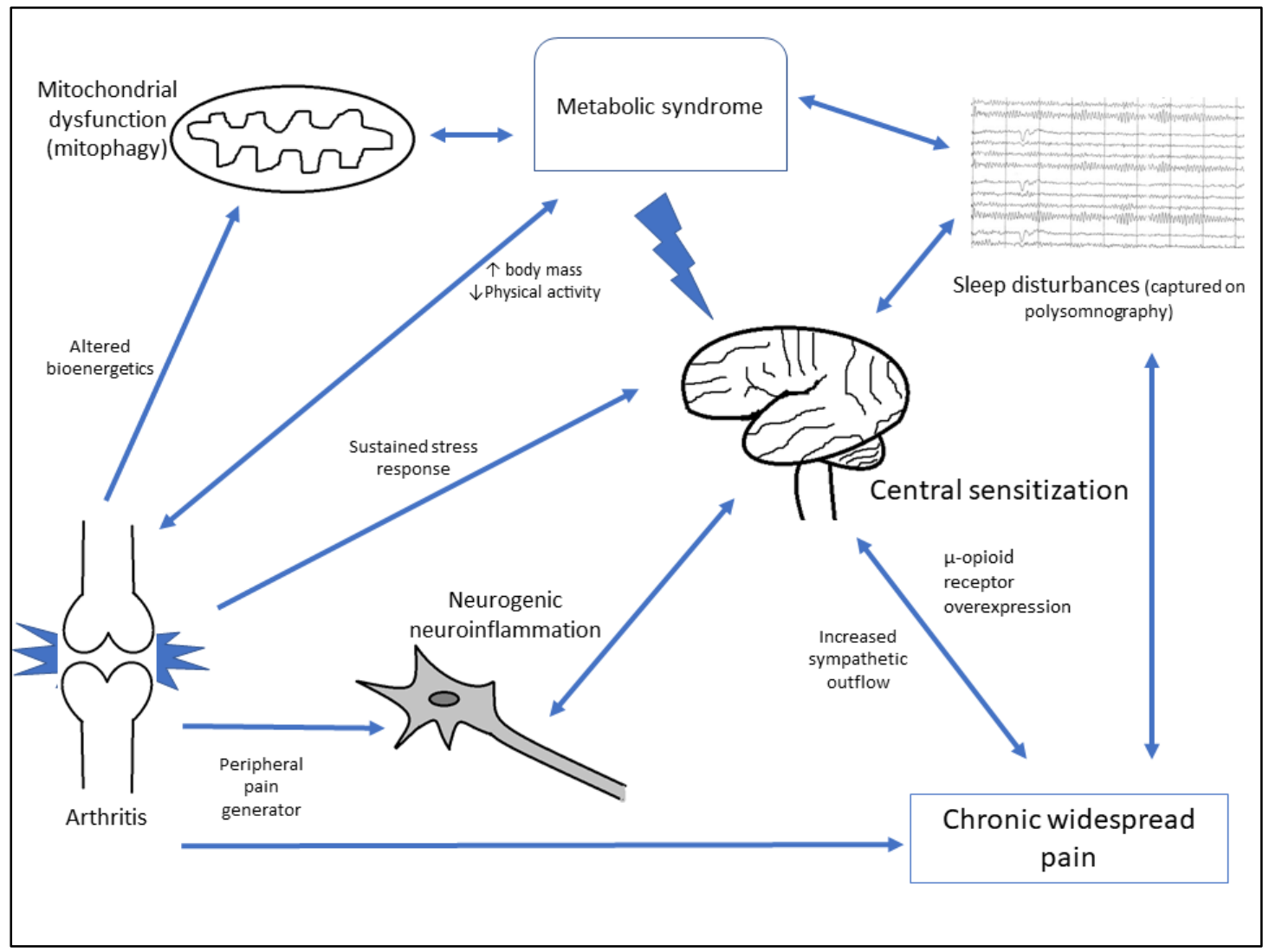

\section{REFERENCES}

1. Heidari F, Afshari M, Moosazadeh M. Prevalence of fibromyalgia in general population and patients, a systematic review and meta-analysis. Rheumatol Int 2017;37(9):1527-1539.

2. Provan SA, Austad C, Halsaa V, Hammer HB, Kvien TK, Uhlig T. Fibromyalgia in patients with rheumatoid arthritis. A 10-year follow-up study, results from the Oslo Rheumatoid Arthritis Register. Clin Exp Rheumatol 2019;37 Suppl 116(1):58-62.

3. Mease PJ. Fibromyalgia, a missed comorbidity in spondyloarthritis: prevalence and impact on assessment and treatment. Curr Opin Rheumatol 2017;29(4):304-310.

4. Torrente-Segarra V, Salman-Monte TC, Rúa-Figueroa Í, Pérez-Vicente S, López-Longo FJ, GalindoIzquierdo $\mathrm{M}$, et al. Fibromyalgia prevalence and related factors in a large registry of patients with systemic lupus erythematosus. Clin Exp Rheumatol 2016;34(2 Suppl 96):S40-S47.

5. Torrente-Segarra V, Corominas H, Sánchez-Piedra C, Fernández-Castro M, Andreu JL, MartínezTaboada VM, et al. Fibromyalgia prevalence and associated factors in primary Sjögren's syndrome patients in a large cohort from the Spanish Society of Rheumatology registry (SJOGRENSER). Clin Exp Rheumatol 2017;35 Suppl 105(3):28-34.

6. Barton JC, Bertoli LF, Barton JC, Acton RT. Fibromyalgia in 300 adult index patients with primary immunodeficiency. Clin Exp Rheumatol 2017;35 Suppl 105(3):68-73.

7. Haliloglu S, Ekinci B, Uzkeser H, Sevimli H, Carlioglu A, Macit PM. Fibromyalgia in patients with thyroid autoimmunity: prevalence and relationship with disease activity. Clin Rheumatol 2017;36(7):1617-1621.

8. Wolfe F, Walitt B, Perrot S, Rasker JJ, Häuser W. Fibromyalgia diagnosis and biased assessment: Sex, prevalence and bias. PloS One 2018;13(9):e0203755. 


\section{Central Asian Journal of Medical Hypotheses and Ethics| \\ 2020; Vol 1}

9. Haliloglu S, Carlioglu A, Akdeniz D, Karaaslan Y, Kosar A. Fibromyalgia in patients with other rheumatic diseases: prevalence and relationship with disease activity. Rheumatol Int 2014;34(9):1275-1280.

10. Salaffi F, Di Carlo M, Carotti M, Sarzi-Puttini P. The subjective components of the Disease Activity Score 28-joints (DAS28) in rheumatoid arthritis patients and coexisting fibromyalgia. Rheumatol Int 2018;38(10):1911-1918.

11. Giacomelli R, Afeltra A, Alunno A, Baldini C, Bartoloni-Bocci E, Berardicurti O, et al. International consensus: What else can we do to improve diagnosis and therapeutic strategies in patients affected by autoimmune rheumatic diseases (rheumatoid arthritis, spondyloarthritides, systemic sclerosis, systemic lupus erythematosus, antiphospholipid syndrome and Sjogren's syndrome)?: The unmet needs and the clinical grey zone in autoimmune disease management. Autoimmun Rev 2017;16(9):911-924.

12. Macfarlane GJ, Barnish MS, Jones GT. Persons with chronic widespread pain experience excess mortality: Iongitudinal results from UK Biobank and meta-analysis. Ann Rheum Dis 2017;76(11):18151822.

13. Gasparyan AY, Ayvazyan L, Blackmore H, Kitas GD. Writing a narrative biomedical review: considerations for authors, peer reviewers, and editors. Rheumatol Int 2011;31(11):1409-1417.

14. Wallace DJ, Bowman RL, Wormsley SB, Peter JB. Cytokines and immune regulation in patients with fibrositis. Arthritis Rheum 1989;32(10):1334-1335.

15. Hader N, Rimon D, Kinarty A, Lahat N. Altered interleukin-2 secretion in patients with primary fibromyalgia syndrome. Arthritis Rheum 1991;34(7):866-872.

16. Maes M, Libbrecht I, Van Hunsel F, et al. The immune-inflammatory pathophysiology of fibromyalgia: increased serum soluble gp130, the common signal transducer protein of various neurotrophic cytokines. Psychoneuroendocrinology 1999;24(4):371-383.

17. Coskun Benlidayi I. Role of inflammation in the pathogenesis and treatment of fibromyalgia. Rheumatol Int 2019;39(5):781-791.

18. Metyas S, Rezk T, Arkfeld D, Leptich T. Autoinflammation and Immunomodulation in Inflammatory Fibromyalgia Syndrome- A Review. Curr Rheumatol Rev 2017;13(2):98-102.

19. Pereira Pernambuco A, de Souza Cota Carvalho L, Pereira Leite Schetino L, Cunha Polese J, de Souza Viana R, d' Ávila Reis D. Effects of a health education program on cytokines and cortisol levels in fibromyalgia patients: a randomized controlled trial. Adv Rheumatol 2018;58(1):21.

20. Parkitny L, Younger J. Reduced Pro-Inflammatory Cytokines after Eight Weeks of Low-Dose Naltrexone for Fibromyalgia. Biomedicines 2017;5(2).

21. Zhang Z, Feng J, Mao A, Le K, La Placa D, Wu X, et al. SNPs in inflammatory genes CCL11, CCL4 and MEFV in a fibromyalgia family study. PloS One 2018;13(6):e0198625.

22. Nollet M, Guisquet A-ML, Belzung C. Models of Depression: Unpredictable Chronic Mild Stress in Mice. Curr Protoc Pharmacol 2013; Chapter 5:Unit 5.65.

23. Gill J, Luckenbaugh D, Charney D, Vythilingam M. Sustained Elevation of Serum Interleukin-6 and Relative Insensitivity to Hydrocortisone Differentiates Posttraumatic Stress Disorder with and Without Depression. Biol Psychiatry 2010;68(11):999-1006.

24. Wallace DJ, Gavin IM, Karpenko O, Barkhordar F, Gillis BS. Cytokine and chemokine profiles in fibromyalgia, rheumatoid arthritis and systemic lupus erythematosus: a potentially useful tool in differential diagnosis. Rheumatol Int 2015;35(6):991-996.

25. Snyder-Mackler N, Sanz J, Kohn JN, Brinkworth JF, Morrow S, Shaver AO, et al. Social status alters immune regulation and response to infection in macaques. Science 2016;354(6315):1041-1045. 


\section{Central Asian Journal of Medical Hypotheses and Ethics| \\ 2020; Vol 1}

26. Kosek E, Altawil R, Kadetoff D, Finn A, Westman M, Le Maître E, et al. Evidence of different mediators of central inflammation in dysfunctional and inflammatory pain--interleukin-8 in fibromyalgia and interleukin-1 $\beta$ in rheumatoid arthritis. J Neuroimmunol 2015;280:49-55.

27. Bäckryd E, Tanum L, Lind A-L, Larsson A, Gordh T. Evidence of both systemic inflammation and neuroinflammation in fibromyalgia patients, as assessed by a multiplex protein panel applied to the cerebrospinal fluid and to plasma. J Pain Res 2017;10:515-525.

28. Bäckryd E, Lind A-L, Thulin M, Larsson A, Gerdle B, Gordh T. High levels of cerebrospinal fluid chemokines point to the presence of neuroinflammation in peripheral neuropathic pain: a cross-sectional study of 2 cohorts of patients compared with healthy controls. Pain 2017;158(12):2487-2495.

29. Littlejohn $G$. Neurogenic neuroinflammation in fibromyalgia and complex regional pain syndrome. Nat Rev Rheumatol 2015;11(11):639-648.

30. Brites D, Fernandes A. Neuroinflammation and Depression: Microglia Activation, Extracellular Microvesicles and microRNA Dysregulation. Front Cell Neurosci 2015;9:476.

31. Hassett AL, Epel E, Clauw DJ, Harris RE, Harte SE, Kairys A, et al. Pain is associated with short leukocyte telomere length in women with fibromyalgia. J Pain Off J Am Pain Soc 2012;13(10):959-969.

32. Tzeng N-S, Chung C-H, Liu F-C, Chiu Y-H, Chang H-A, Yeh C-B, et al. Fibromyalgia and Risk of Dementia-A Nationwide, Population-Based, Cohort Study. Am J Med Sci 2018;355(2):153-161.

33. Bialas AR, Presumey J, Das A, et al. Microglia-dependent synapse loss in type I interferon-mediated lupus. Nature 2017;546(7659):539-543.

34. Clos-Garcia M, Andrés-Marin N, Fernández-Eulate G, et al. Gut microbiome and serum metabolome analyses identify molecular biomarkers and altered glutamate metabolism in fibromyalgia. EBioMedicine 2019; 46:499-511.

35. Mackay M. Lupus brain fog: a biologic perspective on cognitive impairment, depression, and fatigue in systemic lupus erythematosus. Immunol Res 2015;63(1-3):26-37.

36. Bang S, Xie Y-K, Zhang Z-J, Wang Z, Xu Z-Z, Ji R-R. GPR37 regulates macrophage phagocytosis and resolution of inflammatory pain. J Clin Invest 2018;128(8):3568-3582.

37. Calcia MA, Bonsall DR, Bloomfield PS, Selvaraj S, Barichello T, Howes OD. Stress and neuroinflammation: a systematic review of the effects of stress on microglia and the implications for mental illness. Psychopharmacology (Berl) 2016;233(9):1637-1650.

38. Pagliusi MOF, Bonet IJM, Dias EV, et al. Social defeat stress induces hyperalgesia and increases truncated BDNF isoforms in the nucleus accumbens regardless of the depressive-like behavior induction in mice. Eur J Neurosci. 2018 Jun 9; [Epub ahead of print].

39. Kakuta Y, Kawai Y, Okamoto D, et al. NUDT15 codon 139 is the best pharmacogenetic marker for predicting thiopurine-induced severe adverse events in Japanese patients with inflammatory bowel disease: a multicenter study. J Gastroenterol 2018;53(9):1065-1078.

40. Hollis F, Kabbaj M. Social Defeat as an Animal Model for Depression. ILAR J 2014;55(2):221-232.

41. Rose J, Rillich J, Stevenson PA. Chronic social defeat induces long-term behavioral depression of aggressive motivation in an invertebrate model system. PloS One 2017;12(9):e0184121.

42. Ramirez K, Fornaguera-Trías J, Sheridan JF. Stress-Induced Microglia Activation and Monocyte Trafficking to the Brain Underlie the Development of Anxiety and Depression. Curr Top Behav Neurosci 2017;31:155-172.

43. Yavne Y, Amital D, Watad A, Tiosano S, Amital H. A systematic review of precipitating physical and psychological traumatic events in the development of fibromyalgia. Semin Arthritis Rheum 2018;48(1):121-133.

44. Branco J, Atalaia A, Paiva T. Sleep cycles and alpha-delta sleep in fibromyalgia syndrome. J Rheumatol 1994;21(6):1113-1117. 


\section{Central Asian Journal of Medical Hypotheses and Ethics| \\ 2020; Vol 1}

45. Choy EHS. The role of sleep in pain and fibromyalgia. Nat Rev Rheumatol 2015;11(9):513-520.

46. Meresh ES, Artin H, Joyce C, et al. Obstructive sleep apnea co-morbidity in patients with fibromyalgia: a single-center retrospective analysis and literature review. Open Access Rheumatol 2019;11:103-109.

47. Sangle SR, Tench CM, D'Cruz DP. Autoimmune rheumatic disease and sleep: a review. Curr Opin Pulm Med 2015;21(6):553-556.

48. Elenkov IJ, Wilder RL, Chrousos GP, Vizi ES. The sympathetic nerve--an integrative interface between two supersystems: the brain and the immune system. Pharmacol Rev 2000;52(4):595-638.

49. Kaplan R, Robinson CA, Scavulli JF, Vaughan JH. Propranolol and the treatment of rheumatoid arthritis. Arthritis Rheum 1980;23(2):253-255.

50. Koopman FA, Chavan SS, Miljko S, Grazio S, Sokolovic S, Schuurman PR, et al. Vagus nerve stimulation inhibits cytokine production and attenuates disease severity in rheumatoid arthritis. Proc Natl Acad Sci 2016;113(29):8284-8289.

51. Koopman FA, van Maanen MA, Vervoordeldonk MJ, Tak PP. Balancing the autonomic nervous system to reduce inflammation in rheumatoid arthritis. J Intern Med 2017;282(1):64-75.

52. Martínez-Martínez L-A, Mora T, Vargas A, Fuentes-Iniestra M, Martínez-Lavín M. Sympathetic nervous system dysfunction in fibromyalgia, chronic fatigue syndrome, irritable bowel syndrome, and interstitial cystitis: a review of case-control studies. J Clin Rheumatol 2014;20(3):146-150.

53. de Tommaso M, Ricci K, Libro G, Vecchio E, Delussi M, Montemurno A, et al. Pain Processing and Vegetative Dysfunction in Fibromyalgia: A Study by Sympathetic Skin Response and Laser Evoked Potentials. Pain Res Treat 2017;2017:9747148.

54. Albrecht PJ, Hou Q, Argoff CE, Storey JR, Wymer JP, Rice FL. Excessive peptidergic sensory innervation of cutaneous arteriole-venule shunts (AVS) in the palmar glabrous skin of fibromyalgia patients: implications for widespread deep tissue pain and fatigue. Pain Med Malden Mass 2013;14(6):895-915.

55. Lee YH, Kim J-H, Song GG. Association between the COMT Val158Met polymorphism and fibromyalgia susceptibility and fibromyalgia impact questionnaire score: a meta-analysis. Rheumatol Int 2015;35(1):159-166.

56. Baron R, Hans G, Dickenson AH. Peripheral input and its importance for central sensitization. Ann Neurol 2013;74(5):630-636.

57. Üçeyler N, Zeller D, Kahn A-K, Kewenig S, Kittel-Schneider S, Schmid A, et al. Small fibre pathology in patients with fibromyalgia syndrome. Brain J Neurol 2013;136(Pt 6):1857-1867.

58. Levine TD, Saperstein DS. Routine use of punch biopsy to diagnose small fiber neuropathy in fibromyalgia patients. Clin Rheumatol 2015;34(3):413-417.

59. Ramírez M, Martínez-Martínez L-A, Hernández-Quintela E, Velazco-Casapía J, Vargas A, MartínezLavín M. Small fiber neuropathy in women with fibromyalgia. An in vivo assessment using corneal confocal bio-microscopy. Semin Arthritis Rheum 2015;45(2):214-219.

60. Park D-J, Kim S-H, Nah S-S, et al. Polymorphisms of the TRPV2 and TRPV3 genes associated with fibromyalgia in a Korean population. Rheumatology (Oxford) 2016;55(8):1518-1527.

61. Vargas-Alarcon G, Alvarez-Leon E, Fragoso J-M, et al. A SCN9A gene-encoded dorsal root ganglia sodium channel polymorphism associated with severe fibromyalgia. BMC Musculoskelet Disord 2012;13:23.

62. Birnbaum J, Lalji A, Saed A, Baer AN. Biopsy-Proven Small-Fiber Neuropathy in Primary Sjögren's Syndrome: Neuropathic Pain Characteristics, Autoantibody Findings, and Histopathologic Features. Arthritis Care Res 2019;71(7):936-948. 


\section{Central Asian Journal of Medical Hypotheses and Ethics| \\ 2020; Vol 1}

63. Lee J-Y, Choi S-H, Park K-S, et al. Comparison of complex regional pain syndrome and fibromyalgia: Differences in beta and gamma bands on quantitative electroencephalography. Medicine (Baltimore) 2019;98(7):e14452.

64. Loevinger BL, Muller D, Alonso C, Coe CL. Metabolic syndrome in women with chronic pain. Metabolism 2007;56(1):87-93.

65. Malatji BG, Meyer $\mathrm{H}$, Mason S, et al. A diagnostic biomarker profile for fibromyalgia syndrome based on an NMR metabolomics study of selected patients and controls. BMC Neurol 2017;17(1):88.

66. Alcocer-Gómez E, Garrido-Maraver J, Bullón P, et al. Metformin and caloric restriction induce an AMPKdependent restoration of mitochondrial dysfunction in fibroblasts from Fibromyalgia patients. Biochim Biophys Acta 2015;1852(7):1257-1267.

67. Sánchez-Domínguez B, Bullón P, Román-Malo L, et al. Oxidative stress, mitochondrial dysfunction and, inflammation common events in skin of patients with Fibromyalgia. Mitochondrion 2015;21:69-75.

68. Culmsee C, Michels S, Scheu S, Arolt V, Dannlowski U, Alferink J. Mitochondria, Microglia, and the Immune System-How Are They Linked in Affective Disorders? Front Psychiatry 2018;9:739.

69. Rivat C, Ballantyne J. The dark side of opioids in pain management: basic science explains clinical observation. PAIN Rep 2016;1(2):e570.

70. Ferrini F, Trang T, Mattioli T-AM, et al. Morphine hyperalgesia gated through microglia-mediated disruption of neuronal Cl- homeostasis. Nat Neurosci 2013;16(2):183-192.

71. Marques AP, Santo A de S do E, Berssaneti AA, Matsutani LA, Yuan SLK. Prevalence of fibromyalgia: literature review update. Rev Bras Reumatol Engl Ed 2017;57(4):356-363.

72. Queiroz LP. Worldwide epidemiology of fibromyalgia. Curr Pain Headache Rep 2013;17(8):356.

\section{Аутоиммунды аурулары бар науқастардағы фибромиалгия патогенезі: гипотезалар шеңберіне шолу}

\section{Түйіндеме}

Кіріспе. Фибромиалгия (ФМ) басқа ревматикалық аурулары бар науқастарда жиі кездеседі. Бұл аурудың белсенділік көрсеткіштерінің жоғарылауына әкеледі және пациенттерге ремиссияға қол жеткізуге мүмкіндік бермейді. Осындай «екіншілік» ФМ патогенезін білу осы ауруларды емдеудегі кейбір қанағаттандырылмаған қажеттіліктерді жоюға көмектеседі. Әдістері: “Екіншілік” ФМ пайда болуы туралы гипотезаларды қалыптастыру үшін MEDLINE және Scopus мәліметтер базасында шолу жүргізілді.

Нәтижелері: ФМ цитокиннің дисфункциясы, нейрогендік қабыну, стресс, ұйқының бұзылуы, симпатикалық белсенділіктің жоғарылауы және ұсақ талшықтардың нейропатиясынан болатындығы анықталды. Бұл фракторлар аутоиммунды және ауто-қабыну ауруларының көпшілігінде күшейеді. Сонымен қатар, ФМ патогенезіндегі осы фракторлардың рөлі туралы мәліметтер сенімді болып көрінеді. Метаболикалық синдром және митохондриялық дисфункция FM-мен де байланысты, бірақ олардың себептері мен салдарларын ажырату қиын.

Қорытынды: ФМ - бұл әртүрлі этиологиялардың үйлесуі нәтижесінде пайда болатын кең таралған фенотип. Осылайша, әртүрлі ревматикалық аурулар үшін жұмыста қарастырылған 6 фрактордың да болуы немесе жоғарылауы, сезімтал адамдарда екіншілік ФМ деңгейінің төмендеуіне әкелуі мүмкін.

Түйін сөздер: Фибромиалгия, патогенез, Нейроқабыну, Аутоиммунитет, Ауырсыну. Дәйексөз үшін: Ахмед С., Абле Л. Аутоиммунды аурулары бар науқастардағы фрибромиалгия патогенезі: гипотезалар шеңберіне шолу. Медициналық гипотеза мен этиканың Орта Азиялық журналы.- 2020. - №1 (1). - Б. 43 - 54.

https://doi.org/10.47316/cajmhe.2020.1.1.06 


\section{Central Asian Journal of Medical Hypotheses and Ethics| \\ 2020; Vol 1}

Патогенез фибромиалгии у пациентов с аутоиммунными заболеваниями: обзорное исследование для разработки гипотезы

\section{Резюме}

Введение. Распространенность фрибромиалгии (ФМ) у пациентов с другими ревматическими заболеваниями выше, чем в общей популяции. Это приводит к увеличению показателей оценки активности заболевания и не позволяет пациентам достичь ремиссии. Выяснение патогенеза таких «вторичных» ФМ может помочь выяснить неизученные вопросы в лечении этих заболеваний

Методы: На основании материалов таких баз данных как MEDLINE и Scopus было проведено обзорное исследование с целью разработки гипотезы патогенеза вторичной ФМ.

Результаты: Было установлено, что патогенез ФМ обусловлен такими фракторами как: дисфункция цитокинов, нейрогенные нейровоспаление, стресс, нарушения сна, повышенная симпатическая активность и невропатия. Негативное воздействие этих фракторов увеличивается при большинстве аутоиммунных и ауто-воспалительных заболеваний. Данные о роли этих фракторов в патогенезе ФМ кажутся убедительными. Метаболический синдром и митохондриальная дисфуннция также связаны с ФМ, но трудно выявить их причину и следствие.

Вывод: FM является распространенным фенотипом, возникающим в результате сочетанного воздействия различных этиологий. Таким образом, увеличение силы воздействия рассмотренных в работе 6 фракторов при различных ревматических заболеваниях может привести к развитию вторичной ФМ у восприимчивых людях. Ключевые слова: Фибромиалгия, Патогенез, Нейровоспаление, Аутоиммунитет, Боль. Для цитирования: Ахмед С., Абле Л. Патогенез фибромиалгии у пациентов с аутоиммунными заболеваниями: обзорное исследование для разработки гипотезы. Центральноазиатский журнал медицинских гипотез и этики. - 2020. - №1(1). - С. 43 - 54. https://doi.org/10.47316/cajmhe.2020.1.1.06 